\title{
DEVELOPMENT OF PVX RESISTANT POTATO BREEDING LINES USING MARKER-ASSISTED SELECTION
}

\author{
Ercan OZKAYNAK \\ *Yuksel Seed Company. Antalya, TURKEY \\ *Corresponding author: eozkaynak@yukseltohum.com
}

Received: 25.02.2020

\begin{abstract}
Potato breeding requires a long and laborious study as a based on phenotypic and genotypic selection studies due to its tetraploid and heterozygous plant structure. This research was made to show that the variety development can be faster with molecular assisted breeding. In this research, a short breeding program was applied in order to develop new varieties by taking high dry matter content and PVX resistance as the main criterion. The research was carried out between 2014-2019 and 16.000 F1 potato seeds were used as a genetic material. A hard and effective selection breeding, breeder field observation and PVX markers based on tuber and plant characteristics were selected. In this research, fresh market, French fry and chips variety candidates which have high dry matter content, PVX resistant and higher tuber yield compared to commercial varieties have been developed. According to the results of the research; special breeding programs with two selection criteria can be used to shorten the potato breeding time and commercial candidate varieties with superior properties can be developed. Superior lines that showed to be carrying the markers are strongly recommended to be used by breeders to develop new PVX extreme resistance potato varieties.
\end{abstract}

Keywords: Advanced line, genetic advance, potato clones, Solanum tuberosum L., tuber yield

\section{INTRODUCTION}

Potato varieties are developed by crossing hundreds of genotypes and then selection of superior progenies throughout several successive generations in all breeding programs. After crossing, large populations of F1 seedlings are generally grown for visual selection. Single tuber is usually obtained from each F1 plant selected for planting in the next growing season. During the next two to three selection seasons, potato breeding lines are grown and screened for further assessments and propagated to increase seed tuber number. After several years, advanced lines are tested in replicated experiments in several locations to estimate the line $\mathrm{x}$ environment interaction (Carputo et al., 2011; Ozturk and Yildirim, 2011; Ozturk and Yildirim, 2014; Ozkaynak et al., 2018).

The normal breeding period in potato can take over 10 years (Jansky, 2009). Due to its autotetraploid and heterozygous nature, breeding is difficult and continues for a long time. In this heterozygous and autotetraploid genome structure has enabled potato to ready adapt to a wide chancing of environmental conditions through the development of small regionally adapted varieties (Ozkaynak et al., 2018). High levels of genetic heterogeneity have also made possible the development of varieties for different industrial options and applications, such as fresh and traditional market use, French fry, crisp processing and starch production (Slater et al., 2014).
Recent ten years significant advances in molecular genetics and the analysis of highly complex quantitative traits like tuber yield, starch content, can be exploited by potato breeders to accelerate genetic gains, thus enabling more rapid improvements in potato varieties (Slater et al., 2014).

The main criteria for selection in industrial potato are tuber shape and size, eye depth, dry matter content, starch content and reducing sugar content. Selection of varieties were made according to the desired product. French fries varieties should be long tuber, while chips varieties should be round tuber (Gegov et al., 2007; Kirkman, 2007). The dry matter content is a first and important component in industrial processing and determines the internal quality of the product. Dry matter content of French fry varieties should not be below 19.5\% (Kirkman, 2007). In potato chips, the lower limit is around $20 \%$. In addition, the rate of dry matter over $25 \%$ of potato is not suitable. Dry matter content was affected by solar radiation, soil temperature, soil moisture, location, harvest date, fertilization and haulm killing during growing period (Gegov et al., 2007; Haverkort, 2007; Mehta et al., 2011). The accumulation of dry matter content was began during the vegetative growth of the plant and continued until harvest. The root system continues to work as long as there is moisture in the soil. With the defoliation of the haulm there is a sudden decrease in the dry matter in the tuber (Kumari et al., 2018; Storey, 2007). Last fifteen years, potato processing industry is 
emerging as a fast growing industry that more entrepreneurs are investing to this sector while existed ones are increasing their processing capacity (Mehta et al., 2011; Pandey et al., 2009).

Although, last ten years important developments and achievements in molecular tools supply opportunities for rapid genetic income (Slater et al., 2014). But, the use of molecular approaches entail quantitative genetic analysis of the deeply heterozygous breeding populations for development of the complex quality and yield traits with low heritability. Thus, phenotypic selection in potato still remains the common practice in breeding programs. Potato virus $\mathrm{X}(\mathrm{PVX})$ is one of the main potato viruses infecting potato all around the world (Gebhard et al., 2006). PVX can infect trade stocks and cause up to $20 \%$ crop loss (Ahmadvand et al., 2013). Resistance is the most effective method to control this virus. Dominant resistance gene $R x l$ and $R \times 2$ was determined in Solanum tuberosum subsp. andigena (Ahmadvand et al., 2013). Ohbayashi et al. (2010) developed an STS marker linked to Rxl, and the results showed that the recombination frequency was $1.3 \%$. New PVX molecular markers that are tightly linked to the genes were developed for breeding programmes and extreme resistance to PVX (Ahmadvand et al., 2013).

This study was conducted to show that the short-term breeding study can be used in potato for specific purpose (PVX resistant and high dry matter content).

\section{MATERIALS AND METHODS}

\section{Genetic materials}

For selection program, 16 families were created by crossing 24 commercial varieties and breeding lines having different dry matter content and PVX resistance level. List of parents with main characteristics were given in Table 1. Nine thousand two hundred true seeds per family (1200 seed per family, 19.200 in total) were sown into pots for seedling selection in greenhouse in 2014. No selection was applied at the seedling stage. It was not germinated all seeds and at the end of the season, 16.000 single tuber were harvested. At harvest, one tuber per seedling were selected for selection in the first field generation in next season. Hence field selections were started with 16.000 single hills in 2015. After harvest of the first field generation, 800 breeding lines were selected according to main tuber characteristics (tuber shape, tuber size etc.) as visual evaluation. In 2016, 800 breeding lines were planted as a two row (one row 3-5 plant). 125 advanced lines were selected for plant (plant growth and development, earliness etc.) and tuber characteristics (tuber shape, plant tuber yield etc.) as a breeder eye in 2017 (Table 2). The Rx1 marker (for PVX) was used in parents, breeding lines and selected advanced lines. In 2016, 800 lines tested Rx1 molecular marker with one plant fresh leaves. Selected advanced lines (125 lines) in 2017, marker test was made secondly and confirmed PVX marker results. Generally, PVX resistant lines were selected, but some lines of having good tuber features and not resistant PVX also selected. At the end of 2017, 16 superior potato lines were selected. In 2018, 16 advanced breeding lines were planted in two locations using 30-40 tubers in each location as a two rows. In each growing season, commercial important varieties were used as a control variety. VR-808, a crisp processing potato control variety, Madeline and Orchestra, fresh market potato control varieties; Agria and Lady Olympia as a French fry type potato control varieties were used. Field experiments were conducted at highlands of Antalya/Korkuteli $\left(30^{\circ} \mathrm{E}, 37^{\circ} \mathrm{N}, 1100 \mathrm{~m}\right.$ above sea level) in the West-Mediterranean region of Turkey. In 2019, 5 commercial candidates were tested extensively in two locations (Antalya/Korkuteli and Afyonkarahisar/Sandıklı; $30^{\circ} \mathrm{E}, 38^{\circ} \mathrm{N}, 1120 \mathrm{~m}$ above sea level) with control commercial varieties. The experiments were laid out in a Completely Randomized Block Design with four replication. 54 tubers of each selected lines/commercial varieties were planted in two rows in each replication. Tuber yield, starch and dry matter rate were subjected to analysis of variance and differences were compared with LSD tests using MSTAT-C statistic program (Freed et al., 1989).

Table 1. Resistance to PVX and association of $R x 1$ marker and dry matter content of 24 genotypes used as parents in crossings

\begin{tabular}{lclllcll}
\hline Variety & DM $(\%)$ & PVX & & Advanced Line & DM (\%) & PVX \\
\hline Verdi & 22 & $\mathrm{~S}$ & Crisp processing & YP-Ali-13 & 21.4 & $\mathrm{R}$ & French Fry \\
\hline Maradona & 20.1 & $\mathrm{R}$ & Fresh market & $13-73-26$ & 20.8 & $\mathrm{R}$ & $\begin{array}{l}\text { Fresh market and French } \\
\text { Fry }\end{array}$ \\
\hline Madeline & 19.5 & $\mathrm{~S}$ & Fresh market & $12-53-02$ & 19.1 & $\mathrm{~S}$ & Fresh market \\
\hline Desiree & 21.6 & $\mathrm{~S}$ & Fresh market and French Fry & $22-102-71$ & 21.2 & $\mathrm{R}$ & French Fry \\
\hline Florice & 17.6 & $\mathrm{~S}$ & Fresh market & $12-189-06$ & 19 & $\mathrm{~S}$ & Fresh market \\
\hline Granola & 21.2 & $\mathrm{~S}$ & Fresh market & $12-217-03$ & 22.3 & $\mathrm{R}$ & French Fry \\
\hline VR-808 & 23 & $\mathrm{~S}$ & Crisp processing & $12-40-08$ & 21.2 & $\mathrm{~S}$ & Fresh market and French \\
\hline Orchestra & 18.5 & $\mathrm{~S}$ & Fresh market & $12-52-96$ & 18.3 & $\mathrm{R}$ & Fry \\
\hline Volumia & 19.1 & $\mathrm{R}$ & Fresh market & $11--03--38$ & 22.4 & $\mathrm{R}$ & French Fry \\
\hline Touareg & 21 & $\mathrm{~S}$ & Fresh market and French Fry & $12-01-128$ & 20.2 & $\mathrm{~S}$ & Fresh market \\
\hline Victoria & 21.4 & $\mathrm{~S}$ & Fresh market and French Fry & $12-68-42$ & 20.4 & $\mathrm{~S}$ & Fresh market \\
\hline Margit & 20.6 & $\mathrm{R}$ & Fresh market & $12-245-11$ & 18.8 & $\mathrm{~S}$ & Fresh market \\
\hline DM: Dry matter content $(\%)$ & & & &
\end{tabular}


Table 2. Description of breeding program used in this project

\begin{tabular}{|c|c|c|c|c|}
\hline Breeding Stage & No. of year & & & \\
\hline Crossing & 1 & $\begin{array}{l}19.200 \text { potato seed spring and } \\
16.000 \text { one tuber autumn season } \\
\text { (each population } 1000 \text { seed) }\end{array}$ & & 2014 \\
\hline $\begin{array}{l}\text { Primary individual selection } \\
\text { of seedling }\end{array}$ & 2 & 16.000 single hills in field & & 2015 \\
\hline $\begin{array}{l}\text { Secondary individual clonal } \\
\text { selection (4-10 tubers) }\end{array}$ & 3 & $\begin{array}{c}\% 5 \text { hard selection } \\
800 \text { breeding line planted }\end{array}$ & $\begin{array}{l}800 \text { PVX molecular } \\
\text { marker test }\end{array}$ & 2016 \\
\hline $\begin{array}{l}\text { Secondary individual clonal } \\
\text { selection ( } 2-6 \mathrm{~kg} \text { total tuber) }\end{array}$ & 4 & $\begin{array}{l}125 \text { superior breeding line (good } \\
\text { tuber shape, yield, skin and flesh } \\
\text { colour, earliness etc.) }\end{array}$ & $\begin{array}{l}125 \text { superior breeding line } \\
\text { dry matter and PVX test }\end{array}$ & 2017 \\
\hline $\begin{array}{l}\text { Preliminary performance } \\
\text { yield test (60-80 tubers) }\end{array}$ & 5 & $\begin{array}{l}16 \text { candidate variety selected } \\
\text { (minituber production with tissue } \\
\text { culture and large-scale yield test in } \\
\text { two location) }\end{array}$ & 16 candidate variety & 2018 \\
\hline $\begin{array}{l}\text { Commercial Candidate } \\
\text { Lines }\end{array}$ & 6 & 5 variety & & 2019 \\
\hline
\end{tabular}

16 Cross Population

\section{Cultural practices and measured traits}

Seed tubers of breeding lines were planted with $30 \times 70$ $\mathrm{cm}$ planting distance in field conditions. Fertilizers was broadcast at $60-80 \mathrm{~kg} \mathrm{ha}^{-1} \mathrm{~N}, 40-50 \mathrm{~kg} \mathrm{ha}^{-1} \mathrm{P}_{2} \mathrm{O}_{5}$ and $80-$ $100 \mathrm{~kg} \mathrm{ha}^{-1} \mathrm{~K}_{2} \mathrm{O}$ in different experiment fields. Weeds were controlled by hand after emergence. Disease control like PVX, Alternaria spp., Phytophthora infestans and sprinkler irrigation was carried out according to practice. The traits such as maturity, yield, tuber shape, skin and flesh colour, cooking type etc. were determined as a breeder selection. Dry matter content (\%) was measured by Zeal potato hydrometer and starch content $(\%)$ was determined with a polarimetric procedure (Haase, 2003).

\section{DNA isolation and PCR analysis}

Genomic DNA was isolated from young fresh leaves of potato lines using the Wizard Magnetic Kit (Promega) following the manufacturer's instructions. One primers was used for molecular analysis. $R x 1$ gene resistance to PVX was screened using the RxSP-S3 and RxSP-A2 primer sets (Mori et al., 2011; Ohbayashi et al., 2010). The PCR products were separated on a $2 \%$ agarose gel containing TAE buffer at $110 \mathrm{~V}$ for $2 \mathrm{~h}$ and visualized under UV light after staining with ethidium bromide. For PVX resistance, the lines having presence $R x 1$ marker were selected in 800 lines stage 2016, generally.

\section{RESULTS AND DISCUSSION}

Breeding studies are carried out for potato by taking into consideration around 50 different characteristics before the potential is established for new commercial varieties. A breeder will typically select parents for potential pair-wise crossing on the basis of complementary phenotypic characters (Bradshaw and Mackay, 1994; Bradshaw, 2007). These parents will generally be highperforming varieties that require additional improvement, or breeding lines that were proven elite parents and produce higher numbers of superior offspring. It is often important to evaluate new varieties over a number of years and environments, a process that can take over 10 years (Jansky, 2009; Slater et al., 2014). Tarn et al. (1992) reported that at the early stages of selection, parents and crosses play a significant role in breeders' decisions at the later stages of selection when characteristics of the developed individual clones are important.

In this study, twelve special commercial variety and twelve superior advanced line were used as a parent for produce higher numbers of superior lines with high combining ability (Table 1). The varieties Maradona, Volumia and Margit, and advanced breding lines YP-Ali13, 13-73-26, 22-102-71, 12-217-03, 11-3-38 and 12-52-96 were used as parents in the study due to their resistance to PVX with $R x 1$ marker. In 2015, potato lines were selected among 16.000 tubers with a hard selection rate. In 2016, 4 to 12 advanced lines were selected in 16 populations compared to the population. The maximum line was selected from the P2 (Crisp processing x Crisp processing), P9 (French fry x Fresh market), P10 (French fry x Fresh market and French fry), P12 (Fresh market $x$ Fresh market), P13 (Fresh market x French fry), P14 (Fresh market x Fresh market) and P16 (Fresh market $x$ Fresh market) populations, 9 lines and above (Table 3, 4). In 2017, 2-6 kg tubers of 125 lines were planted in double rows in the field. The selection was made in terms of tuber shape, tuber quality, tuber size, earliness, tuber skin colour and tuber flesh colour and yield characteristics (Table 3). 
Table 3. Resistance to PVX and association of Rxl marker and dry matter content of advanced breeding lines (best sample lines of 125 advanced lines)

\begin{tabular}{|c|c|c|c|c|c|c|}
\hline No & $\begin{array}{l}\text { Advanced } \\
\text { Line }\end{array}$ & $\begin{array}{l}\text { DM } \\
(\%)\end{array}$ & VXX & Parents & Important Traits & Candidate Variety \\
\hline 1 & $62-55-07$ & 21.5 & $\mathrm{~S}$ & Margit x VR-808 & Good tuber shape, high dry matter & \\
\hline 5 & $62-55-57$ & 19.5 & $\mathrm{R}$ & Margit x VR-808 & Good tuber shape, high yield,, high quality, white flesh & \\
\hline 9 & $62-59-23$ & 20.6 & $\mathrm{~S}$ & Verdi x VR-808 & Long, big tuber, French fry & \\
\hline 10 & $62-59-34$ & 23 & $\mathrm{~S}$ & Verdi x VR-808 & High yield, good tuber shape & Selected Crisp processing \\
\hline$\overline{11}$ & $62-59-42$ & 21 & $\mathrm{~S}$ & Verdi x VR-808 & good tuber shape, French fry & \\
\hline 12 & $62-59-12$ & 21.7 & $\mathrm{~S}$ & Verdi x VR-808 & Tuber shape, quality super & Selected French Fry \\
\hline 16 & $62-66-05$ & 20.5 & $\mathrm{R}$ & Maradona X Madeline & Good tuber shape, high yield & \\
\hline 18 & $62-66-23$ & 19.5 & $\mathrm{R}$ & Maradona x Madeline & Very high yield, standard, good tuber shape, quality tubers & Selected Fresh market and French Fry \\
\hline 22 & $62-66-39$ & 20.9 & $\mathrm{R}$ & Maradona x Madeline & High yield and quality good tuber shape, medium dry matter & \\
\hline$\overline{27}$ & $62-46-20$ & 17.7 & $\mathrm{R}$ & Maradona $\mathrm{x}$ Desiree & High yield and quality, good tuber shape, super yellow flesh colour & Selected Fresh market \\
\hline 28 & $62-46-56$ & 21.6 & $\mathrm{~S}$ & Maradona $\mathrm{x}$ Desiree & High dry matter, Crisp processing & \\
\hline 33 & $62-64-03$ & 22.8 & $\mathrm{R}$ & $12--40--08 \times 12-52-96$ & High yield, good tuber shape, high dry matter, Crisp processing & \\
\hline 35 & $62-64-39$ & 20.1 & $\mathrm{R}$ & $12--40--08 \times 12-52-96$ & Long French fry, good tuber shape, high quality & \\
\hline$\underline{36}$ & $62-17-64$ & 18.5 & $\mathrm{R}$ & 12--189--06 x Yp-Ali-13 & Big tuber size, medium yield, long tuber shape like Spunta variety & Selected Fresh market \\
\hline$\overline{40}$ & $62-17-\mathrm{S} 6$ & 22.3 & $\mathrm{R}$ & 12-189-06 x Yp-Ali-13 & Big size, early, good tuber shape, high dry matter, French fry and Crisp processing & \\
\hline$\overline{42}$ & $62-50-04$ & 21.7 & $\mathrm{R}$ & 12-01-128 X Margit & High yield, good tuber shape, big tuber size, oval-long tuber & Selected French Fry \\
\hline$\overline{44}$ & $62-50-17$ & 17.5 & $\mathrm{~S}$ & 12-01-128 x Margit & good tuber shape, high quality, long tuber & \\
\hline 49 & $62-61-55$ & 23 & $\mathrm{R}$ & $12-68-42 \times$ Volumia & High yield, oval tuber shape, high dry matter, French fry and Crisp processing & Selected French Fry and Crisp processing \\
\hline 53 & $62-115-64$ & 16.4 & $\mathrm{~S}$ & 12-217-03 x Touareg & Brown tuber skin colour, low dry matter & \\
\hline 56 & $62-115-34$ & 20.7 & $\mathrm{R}$ & $12-217-03 \times$ Touareg & Brown tuber skin colour, medium dry matter, French fry, and Crisp processing & \\
\hline 57 & $62-115-25$ & 19.5 & $\mathrm{R}$ & 12-217-03 x Touareg & Very high yield & Selected Fresh market \\
\hline$\overline{58}$ & $62-115-52$ & 21.1 & $\mathrm{~S}$ & $12-217-03 \times$ Touareg & Brown tuber skin colour, white flesh colour, highly dry matter & \\
\hline 61 & $62-21-06$ & 19.7 & $\mathrm{~S}$ & $11-3-38 \times$ Victoria & Very high yield, medium size tubers, yellow flesh colour, French fry & \\
\hline 64 & $62-21-33$ & 23.0 & $\mathrm{R}$ & $11-3-38 \times$ Victoria & Oval-long tuber, good tuber shape, high yield, yellow flesh colour & Selected French Fry and Crisp Processing \\
\hline 68 & $62-21-19$ & 23 & $\mathrm{~S}$ & $11-3-38 \times$ Victoria & High yield, good tuber shape, Crisp processing & \\
\hline 73 & $62-83-86$ & 22 & $\mathrm{R}$ & $11-03--38 \times$ Orchestra & Super, long tuber shape, White French fry, White flesh colour & Selected French Fry \\
\hline$\overline{76}$ & $62-83-44$ & 21.7 & $\mathrm{~S}$ & $11-03--38 \times$ Orchestra & good tuber shape, long tuber size, high dry matter, French fry & \\
\hline$\overline{79}$ & $62-83-52$ & 21.6 & $\mathrm{R}$ & $11-03--38 \times$ Orchestra & Brown tuber skin colour, like Russet Burbank type, long tuber & Selected French Fry \\
\hline 80 & $62-78-117$ & 19.3 & $\mathrm{~S}$ & Florice $\mathrm{x}$ Orchestra & Very high yield, high quality, medium size tubers, good tuber shape & \\
\hline 83 & $62-78-16$ & 21.5 & $\mathrm{~S}$ & Florice $\mathrm{x}$ Orchestra & High yield, good tuber shape, Crisp processing & \\
\hline 85 & $62-78-23$ & 23.0 & $\mathrm{~S}$ & Florice $\mathrm{x}$ Orchestra & High yield, good tuber shape, high dry matter, French fry and Crisp processing & \\
\hline 89 & $62-78-24$ & 20.5 & $\mathrm{~S}$ & Florice $\mathrm{x}$ Orchestra & High yield, good tuber shape, medium dry matter, Crisp processing & \\
\hline 91 & $62-91-04$ & 18.5 & $\mathrm{R}$ & $13-73-26 \times$ Orchestra & High yield, good tuber shape, Fresh market & Selected Fresh market \\
\hline$\overline{94}$ & $62-91-53$ & 22.5 & $\mathrm{R}$ & $13-73-26 \times$ Orchestra & High yield, round tuber, yellow flesh colour, good tuber shape & Selected Crisp processing \\
\hline 95 & $62-91-67$ & 21.5 & $\mathrm{~S}$ & $13-73-26 \times$ Orchestra & High yield, good tuber shape, medium dry matter & \\
\hline 100 & $62-91-52$ & 23 & $\mathrm{~S}$ & 13-73-26 x Orchestra & Good tuber shape, high dry matter, French fry, Crisp processing & \\
\hline 103 & $62-35-76$ & 20.5 & $\mathrm{~S}$ & $12-53-02$ x Orchestra & Russet Burbank type, long tuber, medium dry matter & \\
\hline$\overline{105}$ & $62-35-11$ & 19.3 & $\mathrm{~S}$ & $12-53-02 \times$ Orchestra & Good tuber shape, Fresh market, low-medium dry matter & \\
\hline 110 & $62-43-02$ & 22.5 & $\mathrm{R}$ & 22-102-71 x Orchestra & Oval, good tuber shape, high yield, long tuber & Selected French Fry \\
\hline$\overline{112}$ & $62-43-S 9$ & 18.5 & $\mathrm{~S}$ & 22-102-71 x Orchestra & Early, good tuber shape, Fresh market & \\
\hline$\overline{113}$ & $62-43-10$ & 23 & $\mathrm{R}$ & 22-102-71 x Orchestra & Tuber shape and quality super, oval-long tuber, high dry matter & Selected French Fry \\
\hline 118 & $62-32-20$ & 19.7 & $\mathrm{~S}$ & $12-245-11 \times$ Granola & Good tuber shape and quality, low-medium dry matter, Crisp processing & \\
\hline 121 & $62-32-09$ & 21.5 & $\mathrm{~S}$ & 12-245-11 x Granola & Long tubers, high yield & Selected French Fry \\
\hline 125 & $62-32-76$ & 20.9 & $\mathrm{~S}$ & 12-245-11 x Granola & pe, medium dry matter, French fry/ Crisp processing & \\
\hline
\end{tabular}


Table 4. Number of selected advanced lines in sixteen potato families

\begin{tabular}{llcclc}
\hline Family & Crossings & $\begin{array}{l}\text { Number of } \\
\text { selected } \\
\text { advanced line }\end{array}$ & Family & Parents & $\begin{array}{l}\text { Number of } \\
\text { selected } \\
\text { advanced line }\end{array}$ \\
\hline P1 & Margit x VR-808 & 5 & P9 & $12-217-03$ x Touareg & 9 \\
\hline P2 & Verdi x VR-808 & 10 & P10 & $11-3-38$ x Victoria & 12 \\
\hline P3 & Maradona x Madeline & 7 & P11 & $11-3-38$ x Orchestra & 7 \\
\hline P4 & Maradona x Desiree & 8 & P12 & Florice x Orchestra & 11 \\
\hline P5 & 12-40-08 x 12-52-96 & 5 & P13 & $13-73-26$ x Orchestra & 10 \\
\hline P6 & 12-189-06 x Yp-Ali-13 & 5 & P14 & $12-53-02$ x Orchestra & 9 \\
\hline P7 & 12-01-128 x Margit & 7 & P15 & $22-102-71$ x Orchestra & 7 \\
\hline P8 & 12-68-42 x Volumia & 4 & P16 & $12-245-11$ x Granola & 9 \\
\hline
\end{tabular}

After harvesting, dry matter content of the tubers were determined. High levels of genetic heterogeneity have enabled the development of varieties for multiple applications, such as fresh market use, French fry and crisp processing, and starch production. Although some selection and breeding may be achieved without detailed genetic knowledge, effective breeding programs are now enhanced by both understanding and utilization of the underlying genetics of the target breeding traits (Slater et al., 2014)

In research, 16 advanced lines having super features were selected in 12 populations in 2017. The majority of the lines selected are candidates for varieties suitable for the French fry potato industry (Table 5). At the end of the experiment in two location, 62-66-23 (Fresh market French Fry), 62-46-20 (Fresh market), 62-61-55 (French Fry-Crisp processing), 62-91-53 (Crisp processing) and 6243-10 (French fry) lines were selected as commercial candidates. Mini-tuber production will be provided in 5 selected commercial candidates and 11 advanced potato lines. Knowledge of the genetic and other environmental influences on the expression of the target traits is important, and will influence methods for the identification of superior parents, screening of the derived populations and effective selection methods to identify superior phenotypes (Slater et al., 2014).

Table 5. PVX resistance and dry matter content of selected advanced breeding lines

\begin{tabular}{|c|c|c|c|c|c|c|}
\hline Family & No & Parents & Line Name & $\mathbf{P V X}^{\mathrm{a}}$ & DM (\%) & Use \\
\hline \multirow[t]{2}{*}{$\mathrm{P} 2$} & YT-1 & Verdi x VR-808 & $62-59-34$ & $\mathrm{~S}$ & 23 & Crisp processing \\
\hline & YT-2 & Verdi x VR-808 & $62-59-12$ & $S$ & 21.7 & French Fry \\
\hline P3 & YT-3 & Maradona x Madeline & $62-66-23$ & $\mathbf{R}$ & 19.5 & $\begin{array}{l}\text { Fresh market-French } \\
\text { Fry }\end{array}$ \\
\hline $\mathrm{P} 4$ & YT-4 & Maradona x Desiree & $62-46-20$ & $\mathbf{R}$ & $\mathbf{1 7 . 7}$ & Fresh market \\
\hline P6 & YT-5 & 12-189-06 x Yp-Ali-13 & $62-17-64$ & $\mathrm{R}$ & 18.5 & Fresh market \\
\hline $\mathrm{P} 7$ & YT-6 & 12-01-128 x Margit & $62-50-04$ & $\mathrm{R}$ & 21.7 & French Fry \\
\hline P8 & YT-7 & 12-68-42 x Volumia & $62-61-55$ & $\mathbf{R}$ & 23 & $\begin{array}{c}\text { French Fry- Crisp } \\
\text { processing }\end{array}$ \\
\hline P9 & YT-8 & 12-217-03 x Touareg & $62-115-25$ & $\mathrm{R}$ & 19.5 & Fresh market \\
\hline $\mathrm{P} 10$ & YT-9 & $11-3-38 \times$ Victoria & $62-21-33$ & $\mathrm{R}$ & 23 & $\begin{array}{l}\text { French Fry- Crisp } \\
\text { processing }\end{array}$ \\
\hline \multirow[t]{2}{*}{$\mathrm{P} 11$} & YT-10 & 11-3-38 x Orchestra & $62-83-86$ & $\mathrm{R}$ & 22 & French Fry \\
\hline & YT-11 & 11-3-38 x Orchestra & $62-83-52$ & $\mathrm{R}$ & 21.6 & French Fry \\
\hline \multirow[t]{2}{*}{ P13 } & YT-12 & 13-73-26 x Orchestra & $62-91-04$ & $\mathrm{~S}$ & 18.5 & Fresh market \\
\hline & YT-13 & 13-73-26 x Orchestra & $62-91-53$ & $\mathbf{R}$ & 22.5 & Crisp processing \\
\hline \multirow[t]{2}{*}{ P15 } & YT-14 & 22-102-71 x Orchestra & $62-43-02$ & $\mathrm{R}$ & 22.5 & French Fry \\
\hline & YT-15 & 22-102-71 x Orchestra & $62-43-10$ & $\mathbf{R}$ & 23 & French Fry \\
\hline P16 & YT-16 & 12-245-11 x Granola & $62-32-09$ & $S$ & 21.5 & French Fry \\
\hline
\end{tabular}

DM : Dry matter content (\%), $\mathrm{PVX}^{\mathrm{a}:} \mathrm{Rx} 1$ marker

Tuber yield is the most important character besides the plant, tuber, agronomic and quality characteristics of potato. Tuber yields were given in Table 6 on two-location basis. If Table 6 were examined, the highest yields were obtained for 62-66-23 and 62-46-20 candidate varieties under combined of two conditions, and variety Madeline, among the commercial control variety, was statistically included in the same group as 62-46-20. The lowest yields were obtained with the commercial varieties Orchestra and Lady Olympia, and among the candidate varieties, 62-9153 was included in the same group as Orchestra variety. But, 62-91-53 line was crisp type potato and average tuber yield (48.6 ton/ha) was higher than commercial variety VR808. All candidate varieties presented higher tuber yield 
than the control varieties except Madeline. Many traits contributing to the phenotype of a potato plant can be highly influenced by the growing environment, like tuber yield, tuber number, tuber size, specific gravity and processing quality (Jansky, 2009; Slater et al., 2014).

The dry matter content and starch content are the two most essential quality criteria for potato. In terms of dry matter, values of $17.9-23.1 \%$ were obtained based on commercial varieties and candidate varieties of the regions of Antalya and Afyonkarahisar (Table 7). It is reported that dry matter content of most potato varieties for commercial usage was ranged about 18-26 (Storey, 2007). The highest dry matter content was provided in the variety candidates 62-43-10 and 62-61-55. Starch is the main component of the tuber dry matter content (Storey, 2007). The distribution in terms of starch content varied between 12.2 $\%$ and $14.6 \%$. Of the candidate varieties, the varieties $62-$ 91-53 and 62-43-10 were given higher starch content than other candidates. In general, higher starch and dry matter content was determined in the Afyonkarahisar region compare to Antalya.

Table 6. Tuber yield results of candidate lines with comparing commercial varieties at two locations in 2019

\begin{tabular}{|c|c|c|c|c|}
\hline \multirow{2}{*}{ Variety/Candidate Line } & \multicolumn{3}{|c|}{ Tuber Yield (ton/ha) } & \multirow[b]{2}{*}{ vS } \\
\hline & Antalya & Afyonkarahisar & Mean & \\
\hline Madeline & $53.5 \mathrm{~b}$ & $61.9 \mathrm{ab}$ & $57.7 \mathrm{~b}$ & 3 \\
\hline Lady Olympia & $43.9 \mathrm{~d}$ & $47.8 \mathrm{f}$ & $45.8 \mathrm{e}$ & 9 \\
\hline VR-808 & $42.9 \mathrm{~d}$ & $49.6 \mathrm{e}$ & $46.2 \mathrm{de}$ & 8 \\
\hline Agria & $57.9 \mathrm{a}$ & $37.7 \mathrm{~g}$ & $47.8 \mathrm{~d}$ & 7 \\
\hline Orchestra & $40.8 \mathrm{de}$ & $50.5 \mathrm{e}$ & $45.6 \mathrm{e}$ & 10 \\
\hline $62-61-55$ & $51.0 \mathrm{bc}$ & $62.2 \mathrm{a}$ & $56.6 \mathrm{~b}$ & 4 \\
\hline $62-66-23$ & $57.7 \mathrm{a}$ & $63.8 \mathrm{a}$ & $60.8 \mathrm{a}$ & 1 \\
\hline $62-46-20$ & $59.9 \mathrm{a}$ & $57.3 \mathrm{c}$ & $58.6 \mathrm{~b}$ & 2 \\
\hline $62-91-53$ & $49.4 \mathrm{bc}$ & $47.9 \mathrm{f}$ & $48.6 \mathrm{~d}$ & 6 \\
\hline $62-43-10$ & $51.7 \mathrm{bc}$ & $50.7 \mathrm{e}$ & $51.2 \mathrm{c}$ & 5 \\
\hline General Mean & 50.9 & 52.9 & 51.9 & \\
\hline Mean of control varieties & 47.8 & 49.5 & 48.9 & \\
\hline$\% \mathrm{CV}$ & 13.45 & 12.73 & 13.09 & \\
\hline $\mathrm{F}$ & $21.18 * *$ & $20.43^{* *}$ & $24.37 * *$ & \\
\hline LSD & 3.28 & 3.17 & 2.58 & \\
\hline
\end{tabular}

Table 7. Dry matter content and starch content results of candidate lines with comparing commercial varieties at two locations in 2019

\begin{tabular}{ccccc}
\hline \multirow{2}{*}{ Variety/Candidate Line } & \multicolumn{2}{c}{ Starch (\%) } & \multicolumn{2}{c}{ DM (\%) } \\
\cline { 2 - 5 } & Antalya & Afyonkarahisar & Antalya & Afyonkarahisar \\
\hline Madeline & $12.7 \mathrm{bc}$ & $13 \mathrm{~b}$ & $19.4 \mathrm{bc}$ & $19.2 \mathrm{bc}$ \\
\hline Lady Olympia & $14.2 \mathrm{a}$ & $14.6 \mathrm{a}$ & $20.9 \mathrm{~b}$ & $20.4 \mathrm{~b}$ \\
\hline Agria & $12.8 \mathrm{bc}$ & $13.3 \mathrm{~b}$ & $19.6 \mathrm{bc}$ & $20.2 \mathrm{~b}$ \\
\hline Orchestra & $12.2 \mathrm{c}$ & $12.6 \mathrm{c}$ & $18.8 \mathrm{c}$ & $18.5 \mathrm{c}$ \\
\hline VR-808 & $14.4 \mathrm{a}$ & $14.6 \mathrm{a}$ & $23 \mathrm{a}$ & $22 \mathrm{ab}$ \\
\hline $62-61-55$ & $13.3 \mathrm{~b}$ & $13.8 \mathrm{ab}$ & $22.4 \mathrm{ab}$ & $19.9 \mathrm{~b}$ \\
\hline $62-66-23$ & $12.6 \mathrm{bc}$ & $13.2 \mathrm{~b}$ & $19.4 \mathrm{bc}$ & $18.5 \mathrm{c}$ \\
\hline $62-46-20$ & $12.5 \mathrm{c}$ & $12.7 \mathrm{c}$ & $17.9 \mathrm{~d}$ & $22.7 \mathrm{ab}$ \\
\hline $62-91-53$ & $14.2 \mathrm{a}$ & $14.6 \mathrm{a}$ & $22.2 \mathrm{ab}$ & $23.1 \mathrm{a}$ \\
\hline $62-43-10$ & $13.9 \mathrm{a}$ & $14.4 \mathrm{a}$ & $22.8 \mathrm{a}$ & 11.76 \\
\hline CV & 11.23 & 10.58 & 12.03 & $19.36^{*}$ \\
\hline F & $13.16^{*}$ & $14.62^{*}$ & $18.26^{*}$ & 1.84 \\
\hline
\end{tabular}

*: Within columns, means followed by the same letter are not significantly different by ANOVA protected LSD test ( $<<0.05)$.

The dry matter content is closely related with the efficiency of transmission of the assimilation products to the tuber (Parlar et al., 2001; Tekalign and Hammes, 2005) and is largely controlled by the genetic structure. Dry matter content is a character that can be affected by ecological conditions, duration of vegetation, soil and plant nutrition characteristics, soil temperature and moisture, solar radiation, cultural treatments besides genetic structure (Slater et al., 2014; Storey, 2007; Yilmaz et al., 2002). The results obtained from the candidate and commercial varieties share similarity with the results of (Asmamaw et al., 2010; Ekin, 2009; Jansky, 2009; Pawelzik et al., 1999) who reported that the dry matter content is affected by environmental factors as well as the genetic structure and 
that generally the varieties with industrial characteristics have a higher dry matter content.

Resistance to disease and pests is important in potato breeding, and the testing of resistance is performed with bioassays and molecular markers. Bioassays are used in the greenhouse or field. However, they are space-consuming and more time is necessary. Therefore, molecular markers that are tightly linked to resistance genes can be used without special facilities for biological evaluation and are not influenced by growth stages or growing conditions (Fullodolsa et al., 2015; Mori et al., 2011). Additionally, molecular markers may reduce costs and increase the precision and efficiency of the selections (Barone, 2004; Fullodolsa et al., 2015; Peleman and der Voort, 2003). In this study, we used molecular markers linked to the $R x I$ gene in potato breeding. PVX occurs commonly worldwide and causes losses of 10-40\% in single infections and is particularly damaging in combination with PVY or PVA (Kreuze et al., 2020).

The introgression of PVX resistance genes into potato varieties are used for controlling the virus and provided extreme resistance to this virus. In the present study, parents, breeding lines and advanced lines were screened with the $R x 1$ marker. In 2016,800 potato lines were tested with the $R x l$ marker. In terms of $R x l$ marker, 446 were found to be resistant according to marker test (unpublished data). Ahmadvand et al., (2013) were obtained that in two F1 populations of crosses showed a 1:1 segregation for PVX resistance (39:36 and 54:42 resistant to susceptible genotypes, respectively). Among 125 advanced lines, 77 lines were found PVX resistant according to $R x l$ marker. While the other lines were not carrier of $R x l$ marker, it cannot be a $100 \%$ warrant for their PVX susceptibility, a fact that would rather be important to consider on further investigations, including virus inoculation test under field conditions and breeding new varieties. The marker produced the expected DNA band in 62-61-55, 62-66-23, 62-46-20, 62-91-53 and 62-43-10 commercial candidate varieties for the $R x l$ gene and these candidates were evaluated as high PVX tolerant varieties according to marker test. Our results were in concordance with previous studies (Ahmadvand et al., 2013; Ohbayashi et al., 2010). Nie et al. (2018) were tested 12 segregating populations (642 plants of progeny) demonstrated its performance with HRM (high-resolution DNA melting) assay. In research, 371 progeny that have possessed Rx1. Shaikhaldein et al. (2018) were tested $R x l$ marker with 28 breeding lines. Among them, three contained Rx1 genes which is extreme resistance to PVX. They reported that these lines are resistance to PVX and have a great potential for gene introgression.

Many characteristics, such as high yield, good quality, and resistance to diseases and pests, are desirable in potato varieties (Asano et al., 2012). From a practical point of view, the introgression of PVX extreme resistance genes into potato varieties would be beneficial both for producer and consumer. Potato varieties are bred by the intercrossing of hundreds of genotypes/lines/varieties of various pedigrees resulting in different gene pools in the different breeding programs, where markers may be inherited, linked to a locus in one pool, but this would not be implicit for another. In the study, the selected lines were classified as resistant or susceptible to PVX. In the study, the 16.000 specific true potato seed lines were propagated and selected 2014 to 2019 with PVX resistance, an acceptable tuber shape, tuber yield and dry matter content continued in the variety development process for subsequent years for the evaluation of agronomic, quality and other disease resistance traits and/or used as parental lines in our selection program. Superior advanced lines were selected from the specific breeding program. Five PVX resistant advanced superior lines were submitted for commercial variety registration. These advanced lines are resistance to PVX and have a great potential for gene introgression. Therefore, it should be recommended that $R x 1$ containing lines be considered as a contribution in potato crop improvement.

\section{ACKNOWLEDGEMENTS}

We gratefully acknowledge the financial support of the Scientific and Technological Research Council of Turkey and its TEYDEP foundation (Projects 3110172, 1140133, 1170041).

\section{LITERATURE CITED}

Ahmadvand, R., I. Wolf, A.M. Gorji, Z. Polgár and J. Taller. 2013. Development of molecular tools for distinguishing between the highly similar Rx1 and Rx2 PVX extreme resistance genes in tetraploid potato. Pot. Res. 56: 277-291.

Asano, K., A. Kobayashi, S. Tsuda, M. Nishinaka and S. Tamiya. 2012. DNA marker-assisted evaluation of potato genotypes for potential resistance to potato cyst nematode pathotypes not yet invading into Japan. Breeding Science. 62: 142-150.

Asmamaw, Y., T. Tekalign and T.S. Workneh. 2010. Specific gravity, dry matter concentration, $\mathrm{pH}$ and crisp-making potential of Ethiopian potato L.) cultivars as influenced by growing environment and length of storage under ambient conditions. Pot. Res. 53: 95-109.

Barone, A. 2004. Molecular marker-assisted selection for potato breeding. Amer. Jour. Pot. Res. 81: 111-117.

Bradshaw, J.E. and G.R. Mackay. 1994. Breeding strategies for clonally propagated potatoes. In: Bradshaw JE, Mackay GR (eds) Potato Genetics. Cab International, Wallingford, pp 467497.

Bradshaw J. 2007. The canon of potato science: four tetrasomic inheritance. Potato Res 50:219-222.

Carputo, D., and L.Frusciante. 2011. Classical Genetics and Traditional Breeding. In: Bradeen, J.M., Kole, C. (Eds.) Genetics, Genomics and Breeding of Potato. Published by Science Publishers. Enfield, NH 03748, USA, 20-40.

Ekin, Z. 2009. Determination of yield and quality characters of some potato (Solanum tuberosum L.) varieties under Ahlat ecological conditions. J. Agric. Fac. HRU. 13(3): 1-10 (In Turkish).

Freed, R., S.P. Einensmith, S. Guetz, D. Reicosky, V.W. Smail and P. Wolberg. 1989. User's Guide to MSTAT-C Analysis of Agronomic Research Experiments. Michigan State Univ. USA.

Fulladolsa, A.C., F.M. Navarro, R. Kota, K. Severson, J.P. Palta and A.O. Charkowski. 2015. Application of marker assisted selection for potato virus $Y$ resistance in the University of Wisconsin Potato Breeding Program. Amer. Jour. Pot. Res. 92: 444-450. 
Gebhardt C, D. Bellin, H. Henselewski, W. Lehmann, J. Schwarzfischer and J.P.T. Valkonen. 2006. Marker assisted combination of major genes for pathogen resistance in potato. Theor. Appl. Genet. 112:1458-1464.

Gegov, Y., G. Pevicharova, E. Nacheva and V. Slavchev. 2007. Potato Breeding Lines Suitable For Production of Frozen French Fries. Bulgarian J. of Agric. Sci. 13: 15-29.

Haase, N.U. 2003. Estimation of dry matter and starch concentration in potatoes by determination of under-water weight and near infrared spectroscopy. Pot. Res. 46(4): 117127.

Haverkort, A. 2007. Potato crop response to radiation and daylength. In: Vreugdenhil D et al., editors. Potato Biology and Biotechnology. Amsterdam: Elsevier Science B.V.; p. 353-365.

Jansky, S. 2009. Breeding, genetics and cultivar development. In: Singh J, Kaur L (eds) Advances in potato chemistry and technology. Academic Press, New York, pp 27-62.

Kirkman, M. 2007. Global markets for processed potato products. In: Vreugdenhil D et al., editors. Potato Biology and Biotechnology. Amsterdam: Elsevier Science B.V. p. 27-44.

Kreuze, F., J.A.C. Sousa-Dias, A. Jeevalatha, A.R. Figueria, J.P.T. Valkonen, R.A.C. Jones. 2020. Viral Diseases in Potato. The Potato Crop. Its Agricultural, Nutritional and Social Contribution to Humankind. H. Campos, O. Ortiz (eds.). Springer, 389-430.

Kumari, M., M. Kumar, and S.S. Solanke. 2018. Breeding Potato for Quality Improvement. In book: Potato - From Incas to All Over the World. Chapter 3: 37-59.

Mehta, A., P. Charaya and B.P. Singh. 2011. French fry quality of potato varieties: effect of tuber maturity and skin curing. Potato J. 38 (2): 130-136.

Mori K, Y. Sakamoto, N. Mukojima, S. Tamiya, T. Nakao, T. Ishii and K. Hosaka. 2011. Development of a multiplex PCR method for simultaneous detection of diagnostic DNA markers of five disease and pest resistance genes in potato. Euphytica. 180: 347-355.

Nie X, V.L. Dickison, S. Brooks, B. Nie, M. Singh, D.L. De Koeyer, A.M. Murphy. 2018. High Resolution DNA Melting Assays for Detection of $R \times 1$ and $R \times 2$ for High-Throughput Marker-Assisted Selection for Extreme Resistance to Potato virus X in Tetraploid Potato. Plant Disease. 102(2): 382-390.

Ohbayashi K, N. Nakato, M. Chaya M and K. Kamura. 2010. Development of a detection method of resistance to potato disease and pest using DNA markers. I detection methods of resistance to potato virus $X$, potato cyst nematode and late blight. Bulletin Nagasaki Agriculture, Forest and Technology Development Center. p. 1-26.
Ozkaynak, E., Y. Orhan and T. Simsek. 2018. Determination of yield performance of early and main season potato commercial candidate varieties. Fresenius Environmental Bulletin. 27(5): 3087-3093.

Ozturk, G. and Z. Yildirim. 2011. Uniformity of Potato Minitubers Derived from Meristem Cultures of Nuclear Seed Stocks. Turkish Journal of Field Crops. 16(2): 149-152.

Ozturk, G. and Z. Yildirim. 2011. Uniformity of Potato Minitubers Derived from Meristem Cultures of Nuclear Seed Stocks. Turkish Journal of Field Crops. 16(2): 149-152.

Pandey, S.K., S.V. Singh, R.S. Marwaha and D. Pattanayak. 2009. Indian potato processing varieties: their impact and future priorities. Potato J. 36: 95-114.

Parlar, H., O. Gschwendtner, A. Anschutz, G. Leupold, and A. Gorg. 2001. Influence of selected parameters on the 2 isoelectric adsorptive bubble separation (iabs) of potato proteins. Advances in Food Sciences. 23(1): 1-10.

Pawelzik, E., E. Delgado, J. Poberezny and I. Rogoziňska. 1999. Effect of different climatic conditions on quality of certain German and Polish potato varieties. Abstract 14th Trien. Conference EAPR, Sorrento. p. 635-636.

Peleman, J.D. and J.R. der Voort. 2003. Breeding by design. Trends Plant Sci. 8: 330-334.

Shaikhaldein, H.O, B. Hoffmann I. A. Alaraidh D.G. Aseel. 2018. Evaluation of extreme resistance genes of Potato virus $\mathrm{X}(\mathrm{Rx} 1$ and $\mathrm{Rx} 2)$ in different potato genotypes. Journal of Plant Diseases and Protection. 125 (1-2): 1-7.

Slater, A.T., N.O.L. Cogan, B. Hayes, L., Schultz, M.F.B. Dale, G.J. Bryan and J. W. Forster. 2014. Improving breeding efficiency in potato using molecular and quantitative genetics. Theor. Appl. Genet. 127: 2279-2292.

Storey, M. 2007. The harvested crop. In: Vreugdenhil D et al., editors. Potato Biology and Biotechnology. Amsterdam: Elsevier Science B.V. p. 441-470

Tarn, T.R., G.C.C. Tai, H. De Jong, A.M. Murphy and J.E.A. Seabrook. 1992. Breeding potatoes for long-day, temperate climates. Janick J, John Wiley \& Sons editors. In Plant Breeding Reviews. 9: 217-332.

Tekalign, T. and P.S. Hammes. 2005. Growth and productivity of potato as influenced by cultivar and reproductive growth: II. Growth analysis, tuber yield and quality. Scientia Horticulturae. 5: 29-44.

Yilmaz, H.A. and L. Gulluoglu. 2002. Determination of agronomic and quality traits of some potato (L.) varieties growing Harran plain. III. Nation Potato Congress, 23-27 September 2002, Izmir, Turkey, p. 179-192 (In Turkish). 